\title{
High-Hydrostatic-Pressure (HHP) Processing Technology as a Novel Control Method for Listeria monocytogenes Occurrence in Mediterranean-Style Dry-Fermented Sausages
}

\author{
Domenico Meloni (1) \\ Department of Veterinary Medicine, University of Sassari, Via Vienna 2, 07100 Sassari, Italy; dmeloni@uniss.it; \\ Tel.: +39-079-229-570; Fax: +39-079-229-458
}

Received: 21 November 2019; Accepted: 9 December 2019; Published: 12 December 2019

\begin{abstract}
Although conventional microbial control techniques are currently employed and largely successful, their major drawbacks are related to their effects on quality of processed food. In recent years, there has been a growing demand for high-quality foods that are microbially safe and retain most of their natural freshness. Therefore, several modern and innovative methods of microbial control in food processing have been developed. High-hydrostatic-pressure (HHP) processing technology has been mainly used to enhance the food safety of ready-to-eat (RTE) products as a new pre-/post-packaging, non-thermal purification method in the meat industry. Listeria monocytogenes is a pertinent target for microbiological safety and shelf-life; due to its capacity to multiply in a broad range of food environments, is extremely complicated to prevent in fermented-sausage-producing plants. The frequent detection of $L$. monocytogenes in final products emphasizes the necessity for the producers of fermented sausages to correctly overcome the hurdles of the technological process and to prevent the presence of $L$. monocytogenes by applying novel control techniques. This review discusses a collection of recent studies describing pressure-induced elimination of L. monocytogenes in fermented sausages produced in the Mediterranean area.
\end{abstract}

Keywords: high hydrostatic pressures; Listeria monocytogenes; Mediterranean; fermented sausages; hurdles technology

\section{Introduction}

In recent years, food business operators (FBOs) have been repeatedly required to meet the request of consumers for more unadulterated, preservative-free, and less-processed food products, without losing their microbiological quality and safety [1]. Although thermal treatments are a powerful technology for the elimination of foodborne pathogens in foods, they can cause alterations of texture and color [2]. Non-thermal technologies, for instance high hydrostatic pressures (HHP), have emerged as new preservation techniques to inactivate the foodborne pathogens present in foods and consequently improve their shelf life [3].

HHP essentially involves the application of isostatic pressures, equally and immediately transmitted to food products by air-driven pumps through a liquid [4]. HHP processing technologies have demonstrated a high capacity to eliminate foodborne pathogens and spoilage bacteria, leading to foods with better microbiological quality and safety [5].

HHP has primarily been used in the ready-to-eat (RTE) meat products industry as a new pre-/post-packaging, non-thermal decontamination method [6]. The implementation of HHP has been proposed to enhance the safety of dry-fermented sausages, since thermal methods may have unsatisfactory effects on their quality $[7,8]$. In these products, the application of HHP could relieve the 
use of nitrites without negative effects on food safety $[9,10]$. Nitrites are routinely used to avoid toxin production by Clostridium botulinum. Furthermore, in fermented meat products, nitrites and/or nitrates are well known for their antagonistic outcomes against the main foodborne pathogens. [11-14]. In the European Union, the quantity of nitrates and nitrites allowed in preserved meat products is outlined in the EC Reg.1129/2011: the permitted quantity is $250 \mathrm{ppm} \mathrm{NaNO}_{3}$ for traditional products without addition of nitrites, or 150/150 ppm $\mathrm{NaNO}_{3} / \mathrm{NaNO}_{2}$ in different cases [15]. Even though the advantages of preservatives are noted, the use of nitrites in meat preservation has caused public concern, since nitrites can be precursors of nitrosamines, many of which are well known to be carcinogenic agents [16]. Therefore, consumers and FBOs are pushing for the development of products with lower amounts of nitrates/nitrites, and some countries are debating a reduction of allowed quantities [15].

Numerous studies have investigated the use of HHP to avoid the presence of L. monocytogenes in several meat products [5,17-24]. HHP has been shown to alter the structure, morphology, and physiology of L. monocytogenes. The effects are related to food composition, time of submission, amount of pressure, and existence of antimicrobial substances [25,26].

L. monocytogenes is a small, non-spore-producing, permissive, anaerobic, Gram-positive rod. Peritrichous flagella enable a characteristic whirling mobility at $20-25^{\circ} \mathrm{C}$. In relation to the presence of somatic $(\mathrm{O})$ and flagellar $(\mathrm{H})$ antigens, thirteen serogroups have been determined: $1 / 2 \mathrm{a}, 1 / 2 \mathrm{~b}, 1 / 2 \mathrm{c}, 3 \mathrm{a}$, $3 \mathrm{~b}, 3 \mathrm{c}, 4 \mathrm{a}, 4 \mathrm{ab}, 4 \mathrm{~b}, 4 \mathrm{c}, 4 \mathrm{~d}, 4 \mathrm{e}$, and 7. L. monocytogenes is catalase-positive, oxidase-negative, and grows between 0 and $45^{\circ} \mathrm{C}$, with an optimum temperature at $30-37^{\circ} \mathrm{C}$.

The pathogen survives at $\mathrm{pH}$ values between 4.5 and 9.0 (optimum $\mathrm{pH}$ 6-8), and can grow in foods with a water activity $\left(\mathrm{a}_{\mathrm{w}}\right)$ of 0.92 . L. monocytogenes is ubiquitous in the ecosystem; the main contamination sources are soil, forage, and water [27,28]. Other reservoirs include healthy humans [29] or contaminated farm and wild animals [30]. L. monocytogenes can multiply at low temperatures, survives under modified atmospheres, and adheres to several surfaces, adapting to disinfectants [31]. Moreover, L. monocytogenes can resist $\mathrm{NaCl}$ (up to $12 \%$ ) and nitrates, which are commonly lethal to other bacteria [32-34].

L. monocytogenes is widespread in food-processing plants; once introduced, it can grow in biofilms and severe conditions, becoming a primary niche of contamination [35-38]. L. monocytogenes is the etiological cause of human listeriosis. This serious invasive disease is nearly completely caused by L. monocytogenes. Uncommon episodes are caused by L. ivanovii and L. seeligeri [32]. L. monocytogenes isolates differ in their pathogenic potential; several strains are innately virulent, causing elevated morbidity and mortality cases, while other strains are non-virulent and not capable of causing illness in humans and animals [32]. Differentiation between virulent and non-virulent isolates is fundamental to evaluating the impact of L. monocytogenes on public health [32].

L. monocytogenes strains have been grouped into three evolutionary lineages differentiated by diverse pathogenic potential: Lineage I includes isolates related to listeriosis outbreaks (serogroups $1 / 2 b, 3 b, 4 b, 4 d$, and $4 \mathrm{e}$ ); Lineage II consists of isolates associated with sporadic human cases (serogroups $1 / 2 a, 1 / 2 c$, 3a, and 3c); and Lineage III includes isolates hardly ever connected with listeriosis outbreaks or sporadic episodes. Most of the listeriosis outbreaks or sporadic episodes are known to be food-borne, and have an impact on the central nervous and circulatory systems and the gravid female uterus. Two types of human listeriosis have been reported, with symptomatology which includes febrile gastroenteritis in healthy people [39], and septicemia and meningoencephalitis in risk categories, such as young, old, pregnant and immune-compromised people, the so-called "YOPI" [40,41].

Listeriosis is the fifth most common zoonotic disease in the European Union, with an annual incidence of 0.48 cases per 100,000 population and 2480 confirmed cases mostly acquired domestically [30]. The highest rates have been reported in Finland, Denmark, Germany, Luxembourg, Sweden, and Belgium, with 1.62, 1.01, 0.88, 0.85, 0.81, and 0.80 cases per 100,000 population, respectively [30]. The lowest rates $(\leq 0.2$ per 100,000$)$ have been reported by Bulgaria, Croatia, Cyprus, Malta, and Romania [30]. 
The highest infection degrees have been outlined in elderly people, mainly aged above 84 years [42]. Listeriosis has the highest hospitalization degree of all zoonoses under European Union surveillance, and $98.6 \%$ of occurrences show additional long-term sequelae [30]. Listeriosis is also the first predominant cause of death in the European Union, with an approximated case fatality rate of $13.8 \%$ [30]. Altogether, 277 deaths were recorded in 2017, the highest number of lethal episodes described since 2006 [30].

The morphology, physiology, and epidemiology of L. monocytogenes, combined with the harshness of human listeriosis, give the presence and the enumeration of the pathogen a certain importance for FBOs of cold-stored RTE food products. L. monocytogenes has been isolated from several RTE foods [43-45] and has been associated with a wide number of outbreaks involving RTE meat, poultry, dairy, fish, and vegetable products [28,46,47].

In the European Union, the food safety criteria for L. monocytogenes in RTE food products are published in the EC Reg. 2073/2005. In RTE foods designated for infants and for special medical purposes, the absence of L. monocytogenes in $25 \mathrm{~g}$ is mandatory. In contrast, in RTE foods able to support the growth of L. monocytogenes ( $\mathrm{pH} \leq 4.4$ or $\mathrm{a}_{\mathrm{w}} \leq 0.92$ or $\mathrm{pH} \leq 5.0$ and $\mathrm{a}_{\mathrm{w}} \leq 0.94$ ), L. monocytogenes cannot exceed $100 \mathrm{CFU} / \mathrm{g}$ throughout the product's shelf life. In the same food products, the absence of L. monocytogenes in $25 \mathrm{~g}$ at the production stage is mandatory. However, the FBOs must confirm that these foods will not exceed the 100 CFU/g during their shelf life. In 2017, the highest level of non-compliance in several RTE foods was reported at the processing stage [30]. The uppermost levels of non-compliance were reported in fish and fishery products $(0.2-3.9 \%)$, followed by soft and semi-soft cheeses $(0.1-2.5 \%)$ and other dairy products $(0-1.5 \%)$. At retail, L. monocytogenes occurrence was uppermost in fish and fishery products $(6 \%)$, followed by salads $(4.2 \%)$, meat and meat products $(1.8 \%)$, soft and semi-soft cheeses $(0.9 \%)$, fruit and vegetables $(0.6 \%)$, and hard cheeses $(0.1 \%)$ [30]. Although a small number of batches of fermented pork sausages were examined and none were positive, fermented sausages contaminated by L. monocytogenes at $>100 \mathrm{CFU} / \mathrm{g}$ and consumed without further heat treatment should be considered a great public health concern [30].

In recent years, much efforts have been put into developing HHP processing technology in order to ascertain the most effective inactivation kinetics of L. monocytogenes in HHP-processed foods [20,48-50]. This review presents a discussion of recently published data focusing on pressure-induced elimination of L. monocytogenes in meat products, mainly fermented sausages produced in the Mediterranean area.

\section{Listeria monocytogenes in the Pork Meat Processing Industry}

\subsection{Swine Slaughterhouses}

The presence of L. monocytogenes has been reported in all the stages of the meat supply chain [51-53], including swine slaughterhouses [54-56]. Even though swine are well known not to be the main carriers of $L$. monocytogenes, pork meat is extremely vulnerable to contamination by L. monocytogenes [57-59].

The main routes of L. monocytogenes contamination can be animal-related or through the slaughterhouse environment $[60,61]$. Due to the ubiquity of L. monocytogenes in swine slaughterhouses, swine carcasses can be contaminated at any stage [61]. L. monocytogenes is propagated to the carcasses from the pigs; it has been periodically found in feces and on the surface of animals in good health with the pathogen present in the intestines $[62,63]$.

The occurrence in feces can reach $50 \%$. Pigs with positive cecal content could have been infected on the farm or throughout transport or the pre-slaughtering interval in highly contaminated lairage areas, which can be considered the primary sources for L. monocytogenes contamination prior to slaughter [56,60,64-66].

The role of pigs as a niche of environmental contamination has been well demonstrated; the area of stunning/hanging is generally the most contaminated [67-70]. The highest prevalence of L. monocytogenes is usually found at the end of dressing, due to handling of the carcasses with contaminated utensils and equipment $[63,71]$. Several authors $[65,66]$ have highlighted that the 
contamination of equipment is related to the occurrence of L. monocytogenes in the tongue (14\%) and tonsils $(7-61 \%)$. At the time of evisceration [72,73], the contamination of carcasses by L. monocytogenes can be around $60 \%-65 \%[53,60,74]$. In slaughterhouse environments, surfaces in contact with meat such as knives, carcass splitters, or dehairing equipment are the most highly contaminated areas and are crucial sites for the cross-contamination of carcasses [56]. The prevalence of L. monocytogenes in meat non-contact surfaces such as floor drains is generally around $20 \%-30 \%$, and is probably correlated with inadequate cleaning procedures [56]. Even though floor drain water is not contemplated as a critical control point, carcass contamination can occur if contaminated water is sprayed at high pressure during cleaning procedures with the consequent formation of aerosols [56].

The monitoring over time of the contamination of slaughterhouses over consecutive sampling sessions can be a useful tool to identify the emergence of new subtypes, as well as the persistence of resident "house strains" [75-77]. Some serogroups of L. monocytogenes can persist in the same ecological niches in the slaughterhouses for months or years, becoming endemic and plant-specific through the formation of biofilms [56]. The most common recurrent serogroups in swine slaughterhouses are $4 \mathrm{~b}$, $1 / 2 a$, and $1 / 2 c[56,65,74,78]$, while serogroup $1 / 2 b$ is generally less frequent.

\subsection{Meat Processing Plants}

Previous authors have reported that the degree of L. monocytogenes contamination increases all along the meat production chain $[53,79]$. The most important magnification niche is the cross-contamination in meat-processing plant environments [63,80-82]. Raw meat is the major source of contamination; a high prevalence is generally found ( $45 \%-50 \%)$, compared to the tissues of recently slaughtered animals $(0 \%-2 \%)[66,74,80,83]$. In general, reception areas, refrigeration, and processing rooms are the most contaminated environments [79]. During the chilling and deboning stages, the presence of L. monocytogenes in chopped meat ranges between $16 \%$ and $50 \%[79,84]$. The amount of contamination increases importantly up to $70 \%-100 \%$ during grinding and bagging [51,74]. At the same time, the occurrence of L. monocytogenes on surfaces in contact and without contact with meat varies between $17 \%$ and $50 \%$ and $11 \%$ and $25 \%$, respectively $[74,85]$.

L. monocytogenes can survive in harsh physical and chemical conditions, forming biofilms on surfaces within the food-processing environment $[32,53,86,87]$. In meat-processing plants, all surfaces and materials are expected to be contaminated by L. monocytogenes (e.g., pipelines, knifes, hooks, gaskets, conveyor belts cutters, slicers, brining and packaging machines, coolers, and freezers, as well as floors and drains) if sanitation is inadequate and/or infrequent. In addition, the more the surfaces show probable harborage niches (hollow parts, crevices, cracks, unpolished or worn materials), the more challenging they are to clean and disinfect and the more L. monocytogenes can settle and colonize them. The capacity of L. monocytogenes to grow in biofilms is thus fundamental for its persistence in food-processing facilities and is well known that these biofilms are the major source of contamination [57-59].

Meat-processing plants represent a suitable environment for the growth of L. monocytogenes biofilms; organic residues can be a niche for its accumulation and biofilm formation, as they are a source of cross-contamination [88]. In particular, meat grinders, worktables, and floor drains can be crucial harborage niches in the meat-processing plant environment [89-93]. In addition, at low temperatures, L. monocytogenes can survive and even increase in numbers as time progresses [58]. L monocytogenes can adhere speedily and tightly to inert surfaces such as metal, glass, rubber, and plastic [57-59]. Previous studies $[85,87,91]$ have shown a persistence of 3-4 months of L. monocytogenes strains with weak or moderate capacity to form biofilms on polystyrene surfaces. The most frequent serogroups of L. monocytogenes found in meat-processing environments are $1 / 2 c$ and $1 / 2 a$, while serogroups $1 / 2 b$ and $4 b$ are generally less frequent. [52,79,85,91]. In general, serogroups $1 / 2 a, 1 / 2 b$, and $4 b$ have shown greater capacity to form biofilms than serogroup 1/2c [91].

Biofilms are a perpetual niche of contamination for foods, and it has been frequently shown that adhered L. monocytogenes strains are more resistant to stress than the planktonic cells $[89,90]$. 
L. monocytogenes entrapped in biofilms is afforded unusual protection against sanitizers and disinfectants [91,94,95]; previous surveys have shown that the suggested concentrations of sanitizers are greater than necessary [38]. Decreases of L. monocytogenes growth in vitro after 24, 48, and $72 \mathrm{~h}$ of exposition to chlorines and quaternary ammonium at $37 \%$ concentration have been previously reported [85].

\section{Production of Fermented Sausages}

The manufacturing of fermented sausages in the Mediterranean area is a dynamic process characterized by biochemical, microbiological, physical, and sensorial changes occurring in minced ground meat formulation during fermentation and ripening [96]. Mediterranean-style dry-fermented sausages are identified by a long shelf life and a generally low sanitary risk due to their low $\mathrm{pH}(<4.5-5)$ and $\mathrm{a}_{\mathrm{w}}(<0.90)$, salt, and nitrites, chemical preservatives. $[40,97,98]$. In "artisanal" sausages, the microbial fermentation is due to natural bacterial microflora consisting mainly of coagulase-negative staphylococci (CNS) and lactic acid bacteria (LAB). In "industrial" sausages, microbial starters are added (especially LAB), in association with powdered milk in order to boost the process of acidification and thus maturation [98].

The safety of fermented sausages is guaranteed by the combination of several environmental parameters, known as "hurdle technology" [99]. The "hurdle technology" concept includes a sequence of different essential hurdles at sequential stages of fermentation and ripening [100]. The synergistic and complementary combination of $\mathrm{pH}$ and $\mathrm{a}_{\mathrm{w}}$ prevent colonization and/or prevent the growth of foodborne pathogens [101]. The simultaneous application of two or more hurdles at low levels provides the same effect that would be achieved by the application at higher levels of a single hurdle [100]. As a result of their sequential application, pathogens and spoilage microorganisms are successfully prevented in fermented sausages, leading to selection for the expected antagonistic microflora, mainly LAB [101]. These hurdles are essential during the fermentation and ripening stages and lead to stable and safe ripened products [99].

The microbial ecosystem of meat fermentation includes a complex and multispecies population; in the early steps, nitrite-curing salts inhibit Pseudomonas bacteria and other Gram-negative microorganisms, which easily grow and damage non-preserved meat in aerobic conditions [99]. Therefore, LAB and CNS are the prevalent microflora coexisting with enterococci, yeasts, and molds $[102,103]$. In general, CNS are prevalent in the early stages of processing.

At the end of maturation, CNS are the second microbial group after LAB [97]. CNS play a fundamental role in the maturation stage: their proteolytic and lipolytic activity, together with the reduction of nitrates, influence the color, flavor, and stability of the ripened sausages [104-106]. CNS can multiply and consume oxygen, resulting in the decline of the redox potential of fermented sausages. The decrease of the redox potential prevents aerobic bacteria and favors the selection of LAB [99].

In Mediterranean sausages, the LAB consist mainly of homofermentative bacilli, while heterofermentative bacilli are less frequent [105]. LAB are characterized by slow growth during the first days of maturation. At the end of the drying stage, they can reach levels of $10^{7}-10^{8} \mathrm{CFU} / \mathrm{g}$ and exceed one billion cells at the end of ripening $[105,106]$. The flourishing of this competitive microflora is mainly due to the metabolism of the added sugars, which in turn produces lactic acid, bacteriocins, and inhibitory metabolites, decreasing the $\mathrm{pH}$ of the sausages [107-112]. Previous studies have shown that the addition of bacteriocins or specific bacteriocin-producing LAB, in association with other preservatives, can enhance the safety and quality of fermented sausages [113-115].

Throughout the fermentation stage, starters and protective cultures control the ecology of foods through so-called "selfish behavior" [116]. This drive towards a harsh environment for unwanted pathogens and spoilage microorganisms allows the manufacturing of fermented sausages characterized by elevated composition benchmarks [117]. LAB are very significant for the safety of short-ripened sausages, which are not highly dried. In long-ripened sausages, nitrites are reduced, and LAB gradually disappear. Conversely, redox potential and $\mathrm{pH}$ rise [99]. Only the $\mathrm{a}_{\mathrm{w}}$ hurdle is reinforced with time, 
becoming predominantly responsible for the microbial safety of long-ripened fermented sausages [101]. The combination of sequential hurdles prevents pathogens and spoilage microorganisms in the innermost part of fermented sausages, while the presence of unwanted molds on the outermost layer of the sausages is prevented by smoking or using desirable mold starter cultures [99].

\section{Listeria monocytogenes in Fermented Sausages}

Depending on the fermentation conditions, L. monocytogenes can persist until the end of ripening or through the storage and marketing of dry-fermented sausages [118]; even so, L. monocytogenes tend to decline greatly during the ripening stage [119]. However, despite the "hurdle technology", the pathogen can become resident in the fermented sausage processing plants and weaken their safety $[40,91,100,120]$. The contamination of fermented meat products by L. monocytogenes may occur at many points of the technological process. The raw meat may be contaminated at the slaughterhouse, during the manufacturing, or by contact with unclean surfaces or workers $[52,79]$ in the post-processing phases [121]. Therefore, the safety of fermented sausages is mainly determined by the management of the fermentation stage [122]. Previous authors have reported occurrence of up to $40 \%-45 \%$ of L. monocytogenes in ripened sausages [40,74,85,87,91,123-128]. Fermented sausages have hardly ever been associated with notable listeriosis outbreaks [30]. However, some critical outbreaks of food-borne listeriosis related to fermented foods have been reported [129]. Even though there is great diversity among the local traditions that affect the management of fermentation and ripening [12], several Mediterranean-style dry-fermented sausages belong to the group of RTE foods where the survival of L. monocytogenes is not assisted. Despite this, in the production of several traditional sausages, empirical management of the "hurdle technology" happens sometimes; for instance, many FBOs are inclined to abbreviate the ripening stage to raise profits for their business [119]. The $\mathrm{pH}$ and $a_{W}$ of fermented sausages at the end of ripening are frequently below the levels necessary for the survival of $L$. monocytogenes [12]. However, not enough dried sausages present $\mathrm{a}_{\mathrm{w}}$ values close to 0.92-0.94 [91] and L. monocytogenes may persist during the fermentation stage, overcoming the various hurdles included in the production process [119]. In a recent study [130], weight loss, $\mathrm{pH}$, and $\mathrm{a}_{\mathrm{w}}$ were estimated as management tools at the ripening stage and used together with predictive mathematical models to assess the persistence of L. monocytogenes in fermented sausages. The decrease of $\mathrm{a}_{\mathrm{w}}$ to safe levels $(<0.92)$ was proved to be closely related to persistence and was confirmed as an easy and useful ripening management tool. L. monocytogenes can replicate in fermented sausages with 12 day ripening only when the values of $\mathrm{a}_{\mathrm{w}}$ are not less than 0.92 [98]. A correct drying process (from 12 to 20 days) is necessary to decrease the $\mathrm{a}_{\mathrm{w}}$, which can reduce the potential of L. monocytogenes survival $(<0.92)[98,119,128]$. In general, in properly ripened fermented sausages, L. monocytogenes cannot compete with the prevailing LAB; therefore, the contamination levels of the pathogen are always $\leq 100$ CFU/g [131]. If antagonistic microflora are lacking, L. monocytogenes can grow up to $>1000 \mathrm{CFU} / \mathrm{g}$, constituting a primary public health problem $[8,52,132]$. The most frequent serogroups found in ripened fermented sausages are $1 / 2 c, 1 / 2 a$, and $1 / 2 b[52,84,85,91]$, while serogroup $4 b$ is rare $[133,134]$.

\section{HHP Processing Technology}

HHP processing is a relatively new, non-thermal method of preserving and sterilizing foods, in which a product already sealed in its final flexible and water-resistant package is processed under very high hydrostatic pressure transmitted by water, leading to the elimination of several microorganisms and enzymes from foods [4]. HHP processes subject foods to an elevated degree of isostatic pressure (300-600MPa/43,500-87,000psi) at room temperature for a few seconds to a few minutes [135]. Although the non-thermal pasteurization outcomes of HHP on food products have been known since the 19th century, it was not until the 1990s that the first HHP food products were developed [135]. Since 2000, HHP processing has been successfully implemented in all types of food industry worldwide [135]. At present, technological HHP processing of foods is performed in a batch or semi-continuous treatment; solid food products can only be processed in a batch mode, whilst liquid products can also be processed 
by means of continuous or semi-continuous treatment [136]. After packaging, food products are laid down in a specifically intended pressure chamber, which is closed and loaded with potable water. A pump joined to the pressure chamber pressurizes the water, (i.e., hydrostatic pressure). The pressure is then transmitted to the food products through the packaging via the water [135]. The isostatic pressures applied to the foods are transferred immediately and are equally distributed; therefore, the treatment is not determined by the form or the extent of the food product [137]. Since the pressure is uniform, the shape is not affected and there is no clear breaking result on the packaging of foods [138]. The pressure is then spread for a fixed time interval, commonly a few seconds but sometimes up to 20 minutes. Once the set interval is completed, the chamber depressurizes and the foods can be taken out [135]. The main benefit of HHP is that the foods are treated regularly all over, which can be difficult to achieve in thermal processing of big or voluminous foods [135].

High pressurization of liquid or solid food products at room temperature is commonly followed by a modest temperature rise $\left(3-6^{\circ} \mathrm{C}\right.$ for every $100 \mathrm{MPa}$ increase in pressure), which is called adiabatic heating and is dependent on the food composition [139]. Food products chill down to the initial temperature upon decompression. No heat is misplaced or accumulated throughout the pressure hold interval [136,140].

Using HHP processing to kill bacteria has many advantages: in usual HHP operations, the high hydrostatic pressure spread to food products at room temperature will decrease the levels of most vegetative bacteria by up to $4 \log$ units or greater, and inactivate certain enzymes with just tiny changes in the composition of foods $[139,140]$. The effectiveness of HHP processing depends on the pressure used, the holding interval, the temperature, the type of food, and the target microorganism $[135,140]$. Nevertheless, the resistance of bacteria and viruses to HHP is extremely inconsistent, e.g., some Gram-positive microorganisms such as L. monocytogenes can present greater resistance than Gram-negative microorganisms such as Salmonella. Spores of both bacteria and molds are highly resistant to HHP inactivation. The resistance of viruses is mainly dependent on their morphological structure [139-141].

\section{Listeria monocytogenes Inactivation Kinetics in Meat Products via HHP Processing Technology}

Frequently used food protection methods are essentially assessed based on their capacity to eliminate foodborne pathogens, thereby enhancing safety and broadening the shelf life of foods through the eradication of spoilage bacteria. HHP has a well-defined benefit in this regard, yielding food products of first-rate quality and nutritional value compared to thermally processed foods [137]. Previous authors have tried to guarantee the HHP inactivation of intentionally spiked or naturally present L. monocytogenes in several cured meat products [8,19-22,24,49,50,142,143].

\subsection{Poultry Meat Products}

Chen et al. [48] showed the outcomes of HHP for the elimination of L. monocytogenes in turkey breast meat. Vacuum-packaged turkey samples were treated at several processing combinations $\left(300 \mathrm{MPa} / 2 \mathrm{~min}, 400 \mathrm{MPa} / 1 \mathrm{~min}\right.$, and $500 \mathrm{MPa} / 1 \mathrm{~min}$ at 1, 10, 20, 30, 40, 50, $55^{\circ} \mathrm{C}$ ). A treatment of $500 \mathrm{MPa} / 1 \mathrm{~min}$ at $40^{\circ} \mathrm{C}$ and $20^{\circ} \mathrm{C}$ had significant effects on the reduction of L. monocytogenes $\left(3.8 \log ^{10}\right.$ and $0.9 \log ^{10} \mathrm{CFU} / \mathrm{g}$, respectively). Patterson, Mackle, and Linton [19] showed the combined outcome of $\mathrm{HHP}\left(600 \mathrm{MPa} / 2 \mathrm{~min} / 20^{\circ} \mathrm{C}\right)$ and sodium lactate $(2 \% \mathrm{w} / \mathrm{w})$ or a pressure-resistant Weissella viridescens strain on the elimination of L. monocytogenes in spiked $\left(\sim 2.2 \times 10^{3} \mathrm{CFU} / \mathrm{g}\right)$ cooked chicken samples stored for up to 105 days at $8^{\circ} \mathrm{C}$. HHP alone was insufficient to inactivate L. monocytogenes $\left(>10^{8} \mathrm{CFU} / \mathrm{g}\right.$ at day 21), and W. viridescens substantially lengthened the lag phase of the L. monocytogenes strains that tolerated the HHP processing. In contrast, the association of sodium lactate and HHP successfully inhibited the occurrence of L. monocytogenes. Myers et al. [144] studied the survival of L. monocytogenes in spiked RTE turkey meat containing sodium nitrite ( 0 or $200 \mathrm{ppm})$ and sodium chloride (1.8 or $2.4 \%)$, treated at 0 and $600 \mathrm{MPa}$ and stored up to 182 days. HHP (600 MPa/3 min) yielded an inactivation of L. monocytogenes between 3.85-4.35 log CFU/g in treated samples. No synergism between HHP 
and sodium nitrite/sodium chloride on the elimination of L. monocytogenes was shown. Stratakos et al. [145] assessed the synergism of coriander oil active film (10\%) and HHP (500 MPa/1 min) on the elimination of L. monocytogenes in chicken breasts stored for 60 days at $4{ }^{\circ} \mathrm{C}$. The association of coriander oil and HHP showed good synergism in keeping the L. monocytogenes count lower than 1.69 $\log \mathrm{CFU} / \mathrm{g}$. Recently, Balamurugan et al. [24] assessed the influence of salt on HHP elimination of L. monocytogenes in pre-blended ground chicken samples. Formulations with $\mathrm{NaCl}, \mathrm{KCl}$, and $\mathrm{CaCl}_{2}$ at three concentrations $(0,1.5$, and $2.5 \%)$ and contaminated with L. monocytogenes $\left(10^{8} \mathrm{CFU} / \mathrm{g}\right)$ were treated with $\operatorname{HHP}(0,100,300$, and $600 \mathrm{MPa}$ for 60 or $180 \mathrm{~s})$. HHP at 100 or $300 \mathrm{MPa}$ and the salts did not significantly decrease L. monocytogenes population. Only at $600 \mathrm{MPa}$ was a synergism between salt and duration of HHP processing on L. monocytogenes inactivation shown. Formulations with increasing concentrations of $\mathrm{CaCl}_{2}$ produced a significantly greater L. monocytogenes inactivation rate.

\subsection{Cooked Pork Hams}

The synergism between enterocins $\mathrm{A}$ and $\mathrm{B}$, sakacin $\mathrm{K}$, nisin, and potassium lactate against spiked L. monocytogenes in sliced cooked ham treated with HHP (400 MPa) was evaluated by Jofré et al. [146]. HHP decreased L. monocytogenes (4 log CFU/g) in all samples including bacteriocins. In contrast, HHP decreased L. monocytogenes in the control and lactate samples, with counts slowly raising to $6.5 \log \mathrm{CFU} / \mathrm{g}$ at the end of storage. Marcos et al. [147] evaluated the effectiveness of $\mathrm{HHP}\left(400 \mathrm{MPa} / 10 \mathrm{~min} / 17^{\circ} \mathrm{C}\right)$ and enterocin active packaging $\left(200 \mathrm{AU} / \mathrm{cm}^{2}\right)$ on the inactivation of L. monocytogenes in spiked cooked ham $\left(10^{4} \mathrm{CFU} / \mathrm{g}\right)$ stored for 90 days at $6{ }^{\circ} \mathrm{C}$ with temperature abuse. HHP and enterocin successfully precluded the growth of L. monocytogenes and kept it at undetectable levels (5 CFU/g) in comparison with untreated samples (8.2-8.8 log CFU/g). In another study, the same authors [148] studied the outcome of HHP $(400 \mathrm{MPa} / 10 \mathrm{~min})$ in association with enterocin and lactate-diacetate on the presence of L. monocytogenes in cooked ham stored for 84 days at 1 or $6{ }^{\circ} \mathrm{C}$, and in presence of temperature abuse. Low temperatures, natural antimicrobials, and HHP caused a decrease of $2.7 \log \mathrm{CFU} / \mathrm{g}$ of L. monocytogenes. In another study, the joined outcomes of nisin $(800 \mathrm{AU} / \mathrm{g})$, potassium lactate $(1.8 \%)$, and $\mathrm{HHP}\left(600 \mathrm{MPa} / 5 \mathrm{~min} / 10^{\circ} \mathrm{C}\right)$ on the inactivation of L. monocytogenes in spiked, vacuum-packed sliced cooked ham $\left(4 \log ^{10} / \mathrm{g}\right)$ stored for 3 months at 1 and $6^{\circ} \mathrm{C}$ was evaluated by the same authors.

The results highlighted that HHP and low temperatures can be successful at challenging survival of L. monocytogenes [149]. The shelf-life prolongation of sliced cooked hams treated with HHP (200 and $\left.400 \mathrm{MPa} / 10 \mathrm{~min} / 17^{\circ} \mathrm{C}\right)$ and enterocin $(256 / 2560 \mathrm{AU} / \mathrm{g})$, stored for 3 months at refrigerated temperature was studied by Liu et al. [150]. The combination of enterocin and HHP $\left(400 \mathrm{MPa} / 10 \mathrm{~min} / 17^{\circ} \mathrm{C}\right)$ was successful in preventing the growth of L. monocytogenes and widening the shelf life of treated samples at 90 days in comparison with control samples. More recently, Bover-Cid et al. [151] evaluated the elimination of spiked L. monocytogenes $\left(10^{7} \mathrm{CFU} / \mathrm{g}\right)$ in HHP-treated $(600 \mathrm{MPa} / 3 \mathrm{~min})$ sliced standard cooked hams. Standard hams were produced with organic acids and control samples without organic acids, but including potassium lactate and sodium diacetate. The inactivation of $L$. monocytogenes was evaluated in vacuum-packaging storage at 8,12 , and $20^{\circ} \mathrm{C}$. In the samples with potassium lactate and sodium diacetate, the growth of L. monocytogenes was barely extended by HHP. In standard cooked hams produced with organic acids, HHP significantly stimulated the growth of L. monocytogenes; at $20{ }^{\circ} \mathrm{C}$, the growth of L. monocytogenes in samples with lactate was up to 4-fold greater than in the untreated products.

\subsection{Dry-Cured Pork Hams}

Bover-Cid et al. [49] conceived and verified a model of the HHP elimination of L. monocytogenes on dry-cured hams (347-852 MPa/2.3 to $15.75 \mathrm{~min} / 7.6$ at $24.4^{\circ} \mathrm{C}$ ). The authors showed that pressure and time were the most important variables influencing the elimination of L. monocytogenes. Stollewerk et al. [152] showed the role of salt and efficacy of HHP ( $600 \mathrm{MPa} / 5 \mathrm{~min})$ in inactivation of L. monocytogenes (spiked at $<100 \mathrm{CFU} / \mathrm{g}$ ) in standard $\mathrm{NaCl}(28 \mathrm{~g} / \mathrm{kg}$ ) and $\mathrm{NaCl}$-free (replaced with 15.31/kg KCl and 
$33.83 / \mathrm{kg}$ potassium lactate) sliced smoked dry cured hams stored at refrigeration temperature for 112 days. HHP successfully inactivated L. monocytogenes in standard samples after 14 days. In contrast, in $\mathrm{NaCl}$-free samples, L. monocytogenes was persistent until 28 and 56 days, respectively. In another study, the same authors [153] manufactured three different dry-cured hams (non-acidified smoked, acidified, and acidified smoked) according to a standard and a $\mathrm{NaCl}$-free recipe. Slices of all the dry-cured hams were inoculated with L. monocytogenes ( $<2 \log \mathrm{CFU} / \mathrm{g})$, treated with $\mathrm{HHP}(600 \mathrm{MPa})$, and stored for 112 days. L. monocytogenes was only inactivated in HHP-treated acidified smoked standard ham slices.

$\mathrm{NaCl}$-free hams displayed delayed inactivation of L. monocytogenes. In another study, Bover-Cid et al. [22] modeled the inactivation of L. monocytogenes in dry-cured ham, in relation to HHP $\left(347-852 \mathrm{MPa} / 5 \mathrm{~min} / 15^{\circ} \mathrm{C}\right), \mathrm{a}_{\mathrm{w}}(0.86-0.96)$, and fat quantity $(10-50 \%)$. The high fat level protected L. monocytogenes against HHP at pressure levels of $\sim 700 \mathrm{MPa}$. At lower pressures, greater elimination of $L$. monocytogenes was shown when the fat level was raised over $30 \%$. In another study, two different RTE dry-cured hams $\left(\mathrm{a}_{\mathrm{W}} 0.92,14.25 \%\right.$ fat and $\mathrm{a}_{\mathrm{w}} 0.88,33.26 \%$ fat $)$ stored for 60 days at $8{ }^{\circ} \mathrm{C}$ were treated with HHP (600 MPa/6 min) with or without use of nisin $\left(200 \mathrm{AU} / \mathrm{cm}^{2}\right)$ and examined for the elimination of L. monocytogenes (spiked at $10^{7}$ cells $/ \mathrm{g}$ ). The inactivation of L. monocytogenes (from 1.85 to $3.58 \mathrm{log}$ ) was high in samples supplemented with nisin. Moreover, $\mathrm{a}_{\mathrm{w}}$ showed an antagonistic $\mathrm{r}$ effect in the elimination of L. monocytogenes: with low $\mathrm{a}_{\mathrm{w}}$ values the inactivation rates were limited [20].

\subsection{Other Meat Products}

Jofré et al. [154] showed the effects of HHP $\left(600 \mathrm{Mpa} / 6 \mathrm{~min} / 31^{\circ} \mathrm{C}\right)$ in protracting the shelf life of marinated beef loins stored for 120 days. HHP was successful in the elimination of L. monocytogenes, which was always below the detection limit in comparison with control samples. HHP elimination (from 300 to $800 \mathrm{MPa}$ ) of L. monocytogenes $\left(10^{7} \mathrm{CFU} / \mathrm{g}\right)$ on mortadella was developed by Hereu et al. [155]. A clear tail shape was shown at pressure values of $>450 \mathrm{MPa}$. At the uppermost degrees (i.e., 727 and $800 \mathrm{MPa}$ ), the L. monocytogenes population declined near to the tail level. The high fat level of mortadella $(\sim 17 \%)$ had a preserving effect on L. monocytogenes from HHP. The same authors [21] evaluated the growth of freeze-stressed or cold-adapted L. monocytogenes strains in mortadella inoculated $\mathrm{T}$ at $10^{7}$ and $10^{4} \mathrm{CFU} / \mathrm{g}$ ) before $\mathrm{HHP}$ processing ( $\left.400 \mathrm{MPa} / 5 \mathrm{~min}\right)$, and thereupon stored at 4,8 , and $12{ }^{\circ} \mathrm{C}$. Freeze-stressed strains were more resistant to HHP and displayed a greatly extended lag phase following HHP processing. The high fat level composition of mortadella affected the survival of L. monocytogenes after HHP treatment. Valdramidis, Patterson, and Linton [23] developed an extended Doehlert model to simulate cured meat treated with HHP (450-800 MPa) and supplemented with sodium chloride/nitrite, as well as the $\mathrm{a}_{\mathrm{w}}$ values (0.95-0.98). The presence of L. monocytogenes was affected by HHP, and HHP showed synergism with $\mathrm{a}_{\mathrm{w}}$ towards preventing the recovery of L. monocytogenes. The concentrations of sodium chloride/nitrite obliquely influenced the occurrence of L. monocytogenes by managing the $\mathrm{a}_{\mathrm{w}}$ values and, therefore, the shelf life of the samples. The lower the $a_{w}$ value, the lower were the inactivation rates caused by HHP.

\section{Listeria monocytogenes Inactivation Kinetics in Fermented Pork Sausages by HHP-Processing Technology}

In recent years, the implementation of HHP has been proposed to improve the safety and protract the shelf life of Mediterranean-style dry-fermented sausages (Table 1), since thermal processing may negatively affect their quality. Marcos, Aymerich, and Garriga [156] manufactured typical Spanish low-acid fermented sausages (named "fuet" and "chorizo") to assess the joined effect of HHP and ripening on inactivation of L. monocytogenes. Raw sausages were treated at $300 \mathrm{MPa}$ for $10 \mathrm{~min}$ at $17^{\circ} \mathrm{C}$, and subsequently ripened at $12{ }^{\circ} \mathrm{C}$ for 27 days. 
Table 1. Listeria monocytogenes inactivation kinetics in HHP-processed fermented sausages.

\begin{tabular}{|c|c|c|c|c|c|}
\hline Product & $\begin{array}{l}\text { HHP Processing } \\
\text { Technology }\end{array}$ & Ripening Time & Inactivation of L. monocytogenes by HHP & Multi-Hurdle Approach & Reference \\
\hline $\begin{array}{l}\text { "Fuet" and "chorizo" } \\
\text { (Spain) }\end{array}$ & $300 \mathrm{MPa} / 10 \mathrm{~min} / 17^{\circ} \mathrm{C}$ & $12{ }^{\circ} \mathrm{C} / 27$ days & from $2.26 \log \mathrm{CFU} / \mathrm{g}$ to $1.42 \mathrm{CFU} / \mathrm{g}$ in fuet & None & Marcos et al., 2005 [156] \\
\hline Fuet (Spain) & $400 \mathrm{MPa}$ & Not defined & $<1 \log \mathrm{CFU} / \mathrm{g}$ at the end of ripening & Enterocins A, B and HHP & Jofrè et al., 2009 [157] \\
\hline “Genoa" salami (Italy) & $\begin{array}{l}600 \mathrm{MPa} \text { or } 483 \mathrm{MPa} / 1 \text { to } \\
12 \mathrm{~min} / 19^{\circ} \mathrm{C}\end{array}$ & $17^{\circ} \mathrm{C} / 25-35$ days & $\begin{array}{l}\text { - } \quad 1.1 \text { to } 1.3 \log \mathrm{CFU} / \mathrm{g} \text { (after fermentation) } \\
\text { - } \quad 1.6 \text { to } \geq 5.0 \log \mathrm{CFU} / \mathrm{g} \text { (after drying) } \\
\quad 3.0 \log \mathrm{CFU} / \mathrm{g} \text { (after storage for } 28 \mathrm{~d} \text { at } \\
4^{\circ} \mathrm{C} \text { ) }\end{array}$ & $\begin{array}{c}\text { Fermentation, drying, and } \\
\text { HHP }\end{array}$ & Porto Fett et al., 2010 [18] \\
\hline Fuet (Spain) & $400 \mathrm{MPa} / 10 \mathrm{~min} / 17^{\circ} \mathrm{C}$ & $15^{\circ} \mathrm{C} / 10$ days & None & Enterocin AS-48 and HHP & Ananou et al., 2010 [17] \\
\hline $\begin{array}{c}\mathrm{NaCl} \text {-free acid (pH 4.8) } \\
\text { and low-acid (pH 5.2) } \\
\text { chorizo (Spain) }\end{array}$ & $600 \mathrm{MPa} / 5 \mathrm{~min} / 13{ }^{\circ} \mathrm{C}$ & Not defined & $<1 \log$ CFU/g at the end of ripening & QDS process $囚$ and $\mathrm{HHP}$ & Stollewerk et al., 2012 [158] \\
\hline $\begin{array}{l}\text { Sodium-salt-free } \\
\text { fermented sausages }\end{array}$ & $600 \mathrm{MPa}\left(5 \mathrm{~min} / 12{ }^{\circ} \mathrm{C}\right.$ & Not defined & None & $\begin{array}{l}\text { HHP and antimicrobial } \\
\text { packaging with films } \\
\text { containing nisin }\end{array}$ & Marcos et al., 2013 [159] \\
\hline Chorizo (Spain) & $349-600 \mathrm{MPa} / 0-12.53 \mathrm{~min} / 18^{\circ} \mathrm{C}$ & $14-15^{\circ} \mathrm{C} / 10$ days & $\begin{array}{l}\quad 2.47 \log \mathrm{CFU} / \mathrm{g} \text { at } 600 \mathrm{MPa} \\
<1 \mathrm{CFU} / \mathrm{g} \text { of } L \text {. monocutogenes in } 100 \% \text { of }\end{array}$ & HHP and water activity & Rubio et al., 2018 [160] \\
\hline Chorizo (Spain) & $400-600 \mathrm{MPa} / 0-12 \mathrm{~min} / 18^{\circ} \mathrm{C}$ & $14-18^{\circ} \mathrm{C} / 21-42$ days & $\begin{array}{l}\text { sausages at the time of consumption (at } \\
600 \mathrm{MPa} / 10-12 \mathrm{~min})\end{array}$ & HHP and nitrite & Possas et al., 2019 [143] \\
\hline
\end{tabular}


A decrease in L. monocytogenes population in treated "fuet" from $2.26 \log \mathrm{CFU} / \mathrm{g}$ to $1.42 \mathrm{CFU} / \mathrm{g}$ at the end of ripening was reported. In contrast, no effects in L. monocytogenes count were noticed in treated "chorizo" samples after 27 days of ripening. The authors highlighted that higher pressure degrees were necessary to eradicate L. monocytogenes cells in ripened fermented sausages. Jofré, Aymerich, and Garriga [157] evaluated the use of extra hurdles such as bacteriocins and/or HHP (400 MPa) in low-acid fermented sausages ("fuet") spiked with L. monocytogenes (3 log CFU/g).

Enterocins A and B displayed a prompt decrease of L. monocytogenes. In contrast, the application of HHP at the end of ripening did not yield the same result. Despite this, an increasing reduction of L. monocytogenes count was noticed throughout storage at room temperature. In another study, Porto-Fett et al. [18] assessed the efficacy of fermentation, drying, and HHP to eliminate spiked L. monocytogenes (about $7.0 \mathrm{log}$ CFU/g) in "Genoa" salami. Elimination of L. monocytogenes after fermentation ranged from roughly 1.1 to $1.3 \log \mathrm{CFU} / \mathrm{g}$. After drying, $\mathrm{HHP}$ at $600 \mathrm{MPa}$ or at $483 \mathrm{MPa}$ for 1 to $12 \mathrm{~min}$ at $19^{\circ} \mathrm{C}$ decreased L. monocytogenes enumeration by a further 1.6 to $\geq 5.0 \log \mathrm{CFU} / \mathrm{g}$. After storage for 28 days at $4{ }^{\circ} \mathrm{C}$, L. monocytogenes enumeration dropped by up to a further $3.0 \mathrm{log}$ $\mathrm{CFU} / \mathrm{g}$. Ananou et al. [17] investigated the single and combined effects of enterocin AS-48 (148 AU g) and HHP (400 MPa for $10 \mathrm{~min}$ at $17^{\circ} \mathrm{C}$ ) on L. monocytogenes inactivation in the Spanish sausage "fuet" throughout ripening for 10 days at $15^{\circ} \mathrm{C}$ and storage at $7{ }^{\circ} \mathrm{C}$ or at room temperature. AS- 48 produced a substantial (5.5 $\log \mathrm{CFU} / \mathrm{g}$ ) decline in L. monocytogenes population. After pressurization and storage, L. monocytogenes numbers stayed below 5 CFU/g in all "fuet" samples, including AS-48 (treated or not).

HHP only had no anti-L. monocytogenes outcome. Stollewerk et al. [158] evaluated the synergism between the QDS process ${ }^{\circledR}$ and HHP $\left(600 \mathrm{MPa} / 5 \mathrm{~min} / 13^{\circ} \mathrm{C}\right)$ on inactivation of L. monocytogenes in $\mathrm{NaCl}$-free acid ( $\mathrm{pH} 4.8$ ) and low-acid ( $\mathrm{pH}$ 5.2) "chorizo" stored at refrigeration temperature for 91 days. HHP resulted in the inactivation of L. monocytogenes during the whole storage time. The reduction of $\mathrm{NaCl}$ could influence the safety of reformulated sausages. However, HHP could be a useful method to develop healthy and safe short-ripened, $\mathrm{NaCl}$-free sausages. Marcos et al. [159] produced sodium-salt-free fermented sausages and spiked L. monocytogenes $\left(10^{7}\right.$ cells/g) onto the outer layer of sausages. The combined outcome of $\operatorname{HHP}\left(600 \mathrm{MPa} / 5 \mathrm{~min} / 12{ }^{\circ} \mathrm{C}\right)$ and antimicrobial wrapping with polyvinyl alcohol layers including nisin was evaluated for elimination of L. monocytogenes throughout a storage time of 90 days at $4{ }^{\circ} \mathrm{C}$.

The results of this study showed that HHP alone did not preclude the rise of L. monocytogenes throughout the storage time. Only the antimicrobial wrapping of fermented sausages with films including nisin caused an evident decrease of L. monocytogenes counts (1.4 log CFU/g). Association of HHP and nisin did not yield any extra protection against L. monocytogenes compared to nisin wrapping alone. Recently, Rubio et al. [160] implemented a central composite design to assess the outcome of $\mathrm{a}_{\mathrm{w}}(0.79-0.92)$, pressure $\left(349-600 \mathrm{MPa}\right.$ at $\left.18^{\circ} \mathrm{C}\right)$, and duration $(0-12.53 \mathrm{~min})$ on HHP-treated L. monocytogenes eradication in Spanish "chorizo" sausages. All the three components greatly affected HHP elimination of L. monocytogenes, as the pressure and holding time of HHP treatments increased.

Slight degrees of $\mathrm{a}_{\mathrm{w}}$ showed a preserving effect on L. monocytogenes, and pressures below $400 \mathrm{MPa}$ did not drive towards considerable pathogen decreases. More recently [143], a stochastic simulation modeling approach to evaluate the degree of L. monocytogenes occurrence on sliced "chorizo" treated or not with HHP after post-process contamination was developed. The effects of dissimilar degrees of L. monocytogenes initial contamination in the minced meat $(-1.43-3 \log \mathrm{CFU} / \mathrm{g}), \mathrm{HHP}$ (400-600 MPa/ $\left.18^{\circ} \mathrm{C} / 0-12 \mathrm{~min}\right)$ and nitrite amounts $(0-150 \mathrm{ppm})$ on L. monocytogenes inactivation were evaluated through predictive models, existing references, and experimental data. In all the simulated outlines, compositions, and storage parameters, the population of L. monocytogenes on sliced vacuum-packed "chorizo" at the marketing stage was assessed to be below $100 \mathrm{CFU} / \mathrm{g}$, and HHP at $600 \mathrm{MPa}$ for 10-12 min was acceptable in non-contaminated samples. 


\section{Conclusions}

The frequent detection of L. monocytogenes in Mediterranean-style ripened sausage emphasizes the necessity for the FBOs to implement a multi-hurdle strategy with HHP to enhance the safety of dry-fermented sausages [141]. The HHP elimination of L. monocytogenes in fermented sausages is greatly dependent on the physicochemical parameters of the sausages. To define specific pressure treatments accomplishing the essential performance criteria, assessment and validation of the efficacy of HHP on specific Mediterranean-style fermented sausages is imperative [143]. The use of HHP processing technology should help Mediterranean FBOs to comply with European regulations on presence and enumeration of L monocytogenes in RTE meat products, as well as optimize the processing conditions of dry-fermented sausages.

Funding: This research received no external funding.

Conflicts of Interest: The author declare no conflict of interest.

\section{References}

1. Falguera, V.; Aliguer, N.; Falguera, M. An integrated approach to current trends in food consumption: moving toward functional and organic products? Food Control 2012, 26, 274-281. [CrossRef]

2. Wang, C.; Huang, H.W.; Hsu, C.P.; Yang, B.B. Recent advances in food processing using high hydrostatic pressure technology. Crit Rev. Food Sci. Nutr. 2016, 56, 527-540. [CrossRef] [PubMed]

3. Tomasula, P.M.; Renye, J.A.; Van Hekken, D.L.; Tunick, M.H.; Kwoczak, R.; Toht, M.; Leggett, L.; Luhansky, J.; Porto-Fett, A.; Phillips, J. Effect of high-pressure processing on reduction of Listeria monocytogenes in packaged Queso Fresco. J. Dairy Sci. 2014, 97, 1281-1295. [CrossRef] [PubMed]

4. Hugas, M.; Garriga, M.; Monfort, J.M. New mild technologies in meat processing: High pressure as a model technology. Meat Sci. 2002, 62, 359-371. [CrossRef]

5. Syed, Q.A.; Buffa, M.; Guamis, B.; Saldo, J. Factors affecting bacterial inactivation during high hydrostatic pressure processing of foods: A review. Crit. Rev. Food Sci. Nutr. 2016, 56, 474-483. [CrossRef] [PubMed]

6. Bajovic, B.; Bolumar, T.; Heinz, V. Quality considerations with high pressure processing of fresh and value added meat products. Meat Sci. 2012, 92, 280-289. [CrossRef] [PubMed]

7. Matser, A.M.; Krebbers, B.; Van Den Berg, R.W.; Bartels, P.V. Advantages of high pressure sterilisation on quality of food products. Trends Food Sci. Technol. 2014, 15, 79-85. [CrossRef]

8. Ducic, M.; Klisara, N.; Markov, S.; Blagojevic, B.; Vidakovic, A.; Buncic, S. The fate and pasteurization-based inactivation of Escherichia coli O157, Salmonella Typhimurium and Listeria monocytogenes in dry, fermented sausages. Food Control 2016, 59, 400-406. [CrossRef]

9. Duranton, F.; Guillou, S.; Simonin, H.; Chéret, R.; De Lamballerie, M. Combined use of high pressure and salt or sodium nitrite to control the growth of endogenous microflora in raw pork meat. Innov. Food Sci. Emerg. Technol. 2012, 16, 373-380. [CrossRef]

10. Fraqueza, M.J.; Borges, A.; Patarata, L. Strategies to reduce the formation of carcinogenic chemicals in dry cured meat products. In Food Control and Biosecurity; Academic Press: Cambridge, MS, USA, 2018; pp. 295-342.

11. Keto-Timonen, R.; Lindström, M.; Puolanne, E.; Niemistö, M.; Korkeala, H. Inhibition of toxigenesis of group II (nonproteolytic) Clostridium botulinum type B in meat products by using a reduced level of nitrite. J. Food Prot. 2012, 75, 1346-1349. [CrossRef]

12. Hospital, X.F.; Hierro, E.; Fernández, M. Effect of reducing nitrate and nitrite added to dry fermented sausages on the survival of Salmonella Typhimurium. Food Res. Int. 2014, 62, 410-415. [CrossRef]

13. Di Gioia, D.; Mazzola, G.; Nikodinoska, I.; Aloisio, I.; Langerholc, T.; Rossi, M.; Raimondi, S.; Melero, B.; Rovira, J. Lactic acid bacteria as protective cultures in fermented pork meat to prevent Clostridium spp. Growth. Int. J. of Food Microbiol. 2016, 235, 53-59. [CrossRef] [PubMed]

14. Hospital, X.F.; Hierro, E.; Stringer, S.; Fernández, M. A study on the toxigenesis by Clostridium botulinum in nitrate and nitrite-reduced dry fermented sausages. Int. J. Food Microbiol. 2016, 218, 66-70. [CrossRef] [PubMed] 
15. Christieans, S.; Picgirard, L.; Para, E.; Lebert, A.; Gregori, T. Impact of reducing nitrate/nitrite levels on the behavior of Salmonella Typhimurium and Listeria monocytogenes in French dry fermented sausages. Meat Sci. 2018, 137, 160-167. [CrossRef]

16. Pegg, R.B.; Shahidi, F. Nitrite curing of meat: The N-nitrosamine problem and nitrite alternatives. In Advanced Technologies for Meat Processing; Food and Nutrition Press: Trumbull, CT, USA, 2000; pp. 209-311.

17. Ananou, S.; Garriga, M.; Jofrè, A.; Aymerich, T.; Galvez, A.; Maqueda, M.; Martínez-Bueno, M.; Valdivia, E. Combined effect of enterocin AS-48 and high hydrostatic pressure to control food-borne pathogens inoculated in low acid fermented sausages. Meat Sci. 2010, 84, 594-600. [CrossRef]

18. Porto-Fett, A.C.S.; Call, J.E.; Shoyer, B.E.; Hill, D.E.; Pshebniski, C.; Cocoma, G.J.; Luchansky, J.B. Evaluation of fermentation, drying, and/or high pressure processing on viability of Listeria monocytogenes, Escherichia coli O157:H7, Salmonella spp., and Trichinella spiralis in raw pork and Genoa salami. Int. J. Food Microbiol. 2010, 140, 61-75. [CrossRef]

19. Patterson, M.F.; Mackle, A.; Linton, M. Effect of high pressure, in combination with antilisterial agents, on the growth of Listeria monocytogenes during extended storage of cooked chicken. Food Microbiol. 2011, 28, 1505-1508. [CrossRef]

20. Hereu, A.; Bover-Cid, S.; Garriga, M.; Aymerich, T. High hydrostatic pressure and biopreservation of dry-cured ham to meet the Food Safety Objectives for Listeria monocytogenes. Int. J. Food Microbiol. 2012, 154, 107-112. [CrossRef]

21. Hereu, A.; Dalgaard, P.; Garriga, M.; Aymerich, T.; Bover-Cid, S. Analysing and modelling the growth behaviour of Listeria monocytogenes on RTE cooked meat products after a high pressure treatment at $400 \mathrm{MPa}$. Int. J. Food Microbiol. 2014, 186, 84-94. [CrossRef]

22. Bover-Cid, S.; Belletti, N.; Aymerich, T.; Garriga, M. Modeling the protective effect of aw and fat content on the high-pressure resistance of Listeria monocytogenes in dry-cured ham. Food Res. Int. 2015, 75, 194-199. [CrossRef]

23. Valdramidis, V.P.; Patterson, M.F.; Linton, M. Modelling the recovery of Listeria monocytogenes in high pressure processed simulated cured meat. Food Control 2015, 47, 353-358. [CrossRef]

24. Balamurugan, S.; Ahmed, R.; Chibeu, A.; Gao, A.; Koutchma, T.; Strange, P. Effect of salt types and concentrations on the high-pressure inactivation of Listeria monocytogenes in ground chicken. Int. J. Food Microbiol. 2016, 218, 51-56. [CrossRef] [PubMed]

25. Alpas, H.; Kalchayanand, N.; Bozoglu, F.; Ray, B. Interactions of high hydrostatic pressure, pressurization temperature and $\mathrm{pH}$ on death and injury of pressure-resistant and pressure-sensitive strains of foodborne pathogens. Int. J. Food Microbiol. 2000, 60, 33-42. [CrossRef]

26. Ferreira, M.; Almeida, A.; Delgadillo, I.; Saraiva, J.; Cunha, A. Susceptibility of Listeria monocytogenes to high pressure processing: a review. Food Rev. Int. 2016, 32, 377-399. [CrossRef]

27. Sauders, B.D.; Wiedmann, M. Ecology of Listeria species and L. monocytogenes in the natural environment. In Listeria, listeriosis, and Food Safety; Ryser, E.T., Marth, E.H., Eds.; Marcel Dekker: New York, NY, USA, 2007; pp. 21-53.

28. Todd, E.C.D.; Notermans, S. Surveillance of listeriosis and its causative pathogen, Listeria monocytogenes. Food Control 2011, 22, 1484-1490. [CrossRef]

29. International Life Sciences Instistute (ILSI) Research Foundation; Risk Science Institute. Achieving continuous improvement in reductions in foodborne listeriosis-A risk-based approach. J. Food Prot. 2005, 68, 1932-1994. [CrossRef]

30. European Food Safety Authority (EFSA); European Centre for Disease Prevention and Control (ECDC). The European Union Summary Report on Trends and Sources of Zoonoses, Zoonotic Agents and Food-borne Outbreaks in 2017. EFSA J. 2018, 16, 1-262.

31. Arevalos-Sánchez, M.; Regalado, C.; Martin, S.E.; Domínguez-Domínguez, J.; García Almendárez, B.E. Effect of neutral electrolyzed water and nisin on Listeria monocytogenes biofilms and on listeriolysin $\mathrm{O}$ activity. Food Control 2012, 24, 116-122. [CrossRef]

32. Gandhi, M.; Chikindas, M.L. Listeria: A foodborne pathogen that knows how to survive. Int. J. Food Microbiol. 2007, 113, 1-15. [CrossRef]

33. Zeng, W.; Vorst, K.; Brown, W.; Marks, B.P.; Jeong, S.; Pérez-Rodríguez, F.; Ryser, E.T. Growth of Escherichia coli O157:H7 and Listeria monocytogenes in Packaged Fresh-Cut Romaine Mix at Fluctuating Temperatures during Commercial Transport, Retail Storage, and Display. J. Food Prot. 2014, 77, 197-206. [CrossRef] 
34. Camargo, A.C.; Woodward, J.J.; Call, D.R.; Nero, L.A. Listeria monocytogenes in food-processing facilities, food contamination, and human listeriosis: the Brazilian scenario. Foodborne Pathog Dis. 2017, 14, 623-636. [CrossRef] [PubMed]

35. Fonnesbech Vogel, B.; Huss, H.H.; Ojeniyi, B.; Ahrens, P.; Gram, L. Elucidation of Listeria monocytogenes contamination routes in cold-smoked salmon processing plants detected by DNA-based typing methods. Appl. Environ. Microbiol. 2001, 67, 2586-2595. [CrossRef] [PubMed]

36. Barros, M.A.; Nero, L.A.; Silva, L.C.; d'Ovidio, L.; Monteiro, F.A.; Tamanini, R.; Fagnani, R.; Hofer, E.; Beloti, V. Listeria monocytogenes: Occurrence in beef and identification of the main contamination points in processing plants. Meat Sci. 2007, 76, 591-596. [CrossRef] [PubMed]

37. Carpentier, B.; Cerf, O. Review-Persistence of Listeria monocytogenes in food industry equipment and premises. Int. J. Food Microbiol. 2011, 145, 1-8. [CrossRef] [PubMed]

38. Cruz, C.D.; Fletcher, G.C. Assessing manufacturers' recommended concentrations of commercial sanitizers on inactivation of Listeria monocytogenes. Food Control 2012, 26, 194-199. [CrossRef]

39. Piana, A.; Are, R.; Orrù, M.; Saba, F.; Dettori, M.; Maida, I.; Sotgiu, G.; Rais, C.; Mura, M.S. Listeria monocytogenes meningoencephalitis: Molecular methods for diagnosis and for monitoring the response to chemotherapy. Ital. J. Public Health 2005, 2, 29-34.

40. De Cesare, A.; Mioni, R.; Manfreda, G. Prevalence of Listeria monocytogenes in fresh and fermented sausages and ribotyping of contaminating strains. Int. J. Food Microbiol. 2007, 120, 124-130. [CrossRef]

41. Sotgiu, G.; Muresu, N.; Dettori, M.; Mura, E.; Cossu, A.; Masia, M.D.; Murgia, P.; Cocuzza, C.; De Santis, E.P.L.; Scarano, C.; et al. A case of Listeria monocytogenes ST-219 meningo-encephalitis. Int. J. Environ. Res Public Health 2019, 1, 8. [CrossRef]

42. Denny, J.; McLauchlin, J. Human Listeria monocytogenes infections in Europe-an opportunity for improved European surveillance. Euro Surveill 2008, 13, 80-82.

43. Romanova, N.; Favrin, S.; Griffiths, M.W. Sensitivity of Listeria monocytogenes to sanitizers used in the meat processing industry. Appl. Environ. Microbiol. 2002, 68, 6405-6409. [CrossRef]

44. Van Coillie, E.; Werbrouck, H.; Heyndrickx, M.; Herman, L.; Rjipens, N. Prevalence and typing of Listeria monocytogenes in Ready-to Eat food products on the Belgian market. J. Food Prot. 2004, 67, 2480-2487. [CrossRef] [PubMed]

45. Shen, Y.; Liu, Y.; Zhang, Y.; Cripe, J.; Conway, W.; Meng, J.; Hall, G.; Bhagwat, A.A. Isolation and characterization of Listeria monocytogenes isolates from ready-to-eat foods in Florida. Appl. Environ. Microbiol. 2006, 72, 5073-5076. [CrossRef] [PubMed]

46. Aureli, P.; Fiorucci, G.C.; Caroli, D.; Marchiaro, G.; Novara, O.; Leone, L.; Salmaso, S. An outbreak of febrile gastroenteritis associated with corn contaminated with Listeria monocytogenes. N. Engl. J. Med. 2000, 342, 1236-1241. [CrossRef] [PubMed]

47. Gillespie, I.A.; McLauchlin, J.; Grant, K.; Little, C.L.; Mithani, V.; Penman, C.; Lane, X.C.; Regan, M. Changing pattern of human listeriosis, England and Wales, 2001-2004. Emerg. Infect. Dis. 2006, 12, 1361-1366. [CrossRef]

48. Chen, H. Use of linear, Weibull, and log-logistic functions to model pressure inactivation of seven foodborne pathogens in milk. Food Microbiol. 2007, 24, 197-204. [CrossRef]

49. Bover-Cid, S.; Belletti, N.; Garriga, M.; Aymerich, T. Model for Listeria monocytogenes inactivation on dry-cured ham by high hydrostatic pressure processing. Food Microbiol. 2011, 28, 804-809. [CrossRef]

50. Possas, A.; Pérez-Rodríguez, F.; Valero, A.; García-Gimeno, R.M. Modelling the inactivation of Listeria monocytogenes by high hydrostatic pressure processing in foods: A review. Trends Food Sci. Technol. 2017, 70, 45-55. [CrossRef]

51. Nesbakken, T.; Kapperud, G.; Caugant, D.A. Pathways of Listeria monocytogenes contamination in the meat processing industry. Int. J. Food Microbiol. 1996, 31, 161-171. [CrossRef]

52. Thévenot, D.; Delignette-Muller, M.L.; Christieans, S.; Leroy, S.; Kodjo, A.; Vernozy-Roland, C. Serological and molecular ecology of Listeria monocytogenes isolates collected from 13 French pork meat salting-curing plants and their products. Int. J. Food Microbiol. 2006, 112, 153-161. [CrossRef]

53. López, V.; Villator, D.; Oertiz, S.; López, P.; Navas, J.; Dávila, J.C.; Martínez-Suarez, J.V. Molecular tracking of Listeria monocytogenes in an Iberian pig abattoir and processing plant. Meat Sci. 2008, 78, 130-134. [CrossRef] 
54. Sammarco, M.L.; Ripabelli, C.; Ruberto, A.; Iannitto, G.; Grasso, G.M. Prevalence of Salmonellae, Listeriae, and Yersinae in the slaughterhouse environment and on work surfaces, equipment, and workers. J. Food Prot. 1997, 60, 367-371. [CrossRef]

55. Korsak, N.; Daube, G.; Ghafir, Y.; Chahed, A.; Jolly, S.; Vindevogel, H. An efficient sampling technique used to detect four foodborne pathogens on pork and beef carcasses in nine Belgian abattoirs. J. Food Prot. 1998, 61,535-541. [CrossRef] [PubMed]

56. Meloni, D.; Piras, F.; Mureddu, A.; Fois, F.; Consolati, S.G.; Lamon, S.; Mazzette, R. Listeria monocytogenes in five Sardinian swine slaughterhouses: Prevalence, Serotype and Genotype Characterization. J. Food Prot. 2013, 76, 1863-1867. [CrossRef] [PubMed]

57. Møretrø, T.; Langsrud, S. Listeria monocytogenes: Biofilm formation and persistence in food-processing environments. Biofilms 2004, 1, 107-121. [CrossRef]

58. Bonaventura, G.; Piccolomini, R.; Paludi, D.; D'Orio, V.; Vergara, A.; Conter, M. Influence of temperature on biofilm formation by Listeria monocytogenes on various food-contact surfaces: Relationship with motility and cell surface hydrophobicity. J. Appl. Microbiol. 2008, 104, 1552-1561. [CrossRef] [PubMed]

59. Bonsaglia, E.C.R.; Silva, N.C.C.; Júnior, A.F.; Júnior, J.A.; Tsunemi, M.H.; Rall, V.L.M. Production of biofilm by Listeria monocytogenes in different materials and temperatures. Food Control 2014, 35, 386-391. [CrossRef]

60. Bonardi, S.; Brindani, F.; Maggi, E. Isolation of Listeria monocytogenes and Listeria spp. from pigs at slaughter in Italy. Ann. Fac Medic Vet. Parma 2002, 22, 205-210.

61. Sereno, M.J.; Viana, C.; Pegoraro, K.; Lopes da Silva, D.A.; Yamatogi, R.S.; Nero, L.A.; dos Santos Bersot, L. Distribution, adhesion, virulence and antibiotic resistance of persistent Listeria monocytogenes in a pig slaughterhouse in Brazil. Food Microbiol. 2019, 84, 103234. [CrossRef]

62. Autio, T.; Sateri, T.; Fredriksson-Ahomaa, M.; Rahkio, M.; Lunden, J.; Korkeala, H. Listeria monocytogenes contamination pattern in pig slaughterhouses. J. Food Prot. 2000, 63, 1438-1442. [CrossRef]

63. Prencipe, V.A.; Rizzi, V.; Acciari, V.; Iannetti, L.; Giovannini, A.; Serraino, A.; Calderone, D.; Rossi, A.; Morelli, D.; Marino, L.; et al. Listeria monocytogenes prevalence, contamination levels and strains characterization throughout the Parma ham processing chain. Food Control 2012, 25, 150-158. [CrossRef]

64. Belœil, P.A.; Chauvin, C.; Toquin, M.T.; Fablet, C.; Le Nŏtre, Y.; Salvat, G. Listeria monocytogenes contamination of finishing pigs: An exploratory epidemiological survey in France. Vet. Res. 2003, 34, 737-748. [CrossRef] [PubMed]

65. Morales-Partera, A.M.; Cardoso-Toset, F.; Luque, I.; Astorga, R.J.; Maldonado, A.; Herrera-Leon, S.; Hernandez, M.; Gomez-Laguna, J.; Tarradas, C. Prevalence and diversity of Salmonella spp., Campylobacter spp., and Listeria monocytogenes in two free-range pig slaughterhouses. Food Control 2018, 92, 208-2015. [CrossRef]

66. Kanuganti, S.R.; Wesley, I.V.; Reddy, P.G.; McKean, J.; Hurd, H.S. Detection of Listeria monocytogenes in pigs and pork. J. Food Prot. 2002, 65, 1470-1474. [CrossRef]

67. Gobat, P.F.; Jemmi, T. Epidemiological studies on Listeria spp. in slaughterhouses. Fleischwirtsch 1991, 1, 44-49.

68. Nesbakken, T.; Nerbrink, E.; Rotterud, O.J.; Borch, E. Reduction of Yersinia enterocolitica and Listeria spp. on pig carcasses by enclosure of the rectum during slaughter. Int. J. Food Microbiol. 1994, 23, 197-208. [CrossRef]

69. Saide-Albornoz, J.J.; Knipe, C.L.; Murano, E.A.; Beran, G.W. Contamination of pork carcasses during slaughter, fabrication, and chilled storage. J. Food Prot. 1995, 58, 993-997. [CrossRef]

70. Borch, E.; Nesbakken, T.; Christensen, H. Hazard identification in swine slaughter with respect to foodborne bacteria. Int. J. Food Microbiol. 1996, 30, 9-25. [CrossRef]

71. Gamboa-Marin, A.; Buitrago, S.; Perez-Perez, K.; Mercado, M.; Poutou-Pinales, R.; Carrascal-Camacho, A. Prevalence of Listeria monocytogenes in pork-meat and other processed products from the Colombian swine industry. Rev. MVZ Córdoba 2012, 17, 2827-2833. [CrossRef]

72. Adesyiun, A.A.; Krishnan, C. Occurrence of Yersinia enterocolitica O:3. Listeria monocytogenes O:4. and thermophilic Campylobacter spp. in slaughter pigs and carcasses in Trinidad. Food Microbiol. 1995, 12, 99-107. [CrossRef]

73. Almeida Iglesias, M.; Schneid Kroning, I.; Tombini Decol, L.; Gombossy de Melo Franco, B.D.; Padilha da Silva, W. Occurrence and phenotypic and molecular characterization of Listeria monocytogenes and Salmonella spp. in slaughterhouses in southern Brazil. Food Res. Int. 2017, 100, 96-101. [CrossRef] 
74. Thévenot, D.; Delignette-Muller, M.L.; Christieans, S.; Vernozy-Roland, C. Prevalence of Listeria monocytogenes in 13 dried sausage processing plants and their products. Int. J. Food Microbiol. 2005, 102, 85-94. [CrossRef] [PubMed]

75. Buncic, S. The incidence of Listeria monocytogenes in slaughtered animals, in meat, and in meat products in Yugoslavia. Int. J. Food Microbiol. 1991, 12, 173-180. [CrossRef]

76. Ripamonti, B.; Zecchini, A.; Colombo, F.; Stella, S.; Cantoni, C. Localizzazione di Listeria monocytogenes e Salmonella spp. nei macelli. Ing. Aliment. 2002, 18,7-13.

77. Autio, T.; Keto-Timonen, R.; Lunden, J.; Bjorkroth, J.; Korkeala, H. Characterisation of persistent and sporadic Listeria monocytogenes strains by pulsed-field gel electrophoresis (PFGE) and amplified fragment length polymorphism (AFLP). Syst. Appl. Microbiol. 2003, 26, 539-545. [CrossRef] [PubMed]

78. Hof, H.; Rocourt, J. Is any strain isolated detected in food a health risk? Int. J. Food Microbiol. 1992, 16, 683-692. [CrossRef]

79. Chasseignaux, E.; Gerault, P.; Toquin, M.; Salvat, G.; Colin, P.; Ermel, G. Ecology of Listeria monocytogenes in the environment of raw poultry meat and raw pork meat processing plants. FEMS Microbiol. Lett. 2002, 210, 271-275. [CrossRef]

80. Giovannacci, I.; Ragimbeau, C.; Queguiner, S.; Salvat, G.; Vendeuvre, J.L.; Carlier, V.; Ermel, G. Listeria monocytogenes in pork slaughtering and cutting plants. Use of RAPD, PFGE and PCR-REA for tracing and molecular epidemiology. Int. J. Food Microbiol. 1999, 53, 127-140. [CrossRef]

81. Lundén, J.M.; Autio, T.J.; Korkeala, H.J. Transfer of persistent Listeria monocytogenes contamination between food-processing plants associated with a dicing machine. J. Food Prot. 2002, 65, 1129-1233. [CrossRef]

82. Muhterem-Uyar, M.; Dalmasso, M.; Bolocan, A.S.; Hernandez, M.; Kapetanakou, A.E.; Kuchta, T.; Manios, S.G.; Melero, B.; Minarovičová, J.; Nicolau, A.I.; et al. Environmental sampling for Listeria monocytogenes control in food processing facilities reveals three contamination scenarios. Food Control 2015, 51, 94-107. [CrossRef]

83. Kathariou, S. Listeria monocytogenes virulence and pathogenicity, a food safety perspective. J. Food Prot. 2002, 65, 1811-1829. [CrossRef]

84. Jay, J. Prevalence of Listeria spp. in meat and poultry products. Food Control 1996, 7, 209-214. [CrossRef]

85. Mureddu, A.; Mazza, R.; Fois, F.; Meloni, D.; Bacciu, R.; Piras, F.; Mazzette, R. Listeria monocytogenes persistence in ready-to-eat sausages and in processing plants. Ital. J. Food Safety 2014, 3, 12-15. [CrossRef]

86. Mafu, A.A.; Roy, D.; Goulet, J.; Magny, P. Attachment of Listeria monocytogenes to stainless steel, glass, polypropylene and rubber surfaces after short contact times. J. Food Prot. 1990, 53, 742-746. [CrossRef] [PubMed]

87. Meloni, D.; Piras, F.; Mureddu, A.; Mazza, R.; Nucera, D.; Mazzette, R. Sources of Listeria monocytogenes contamination in traditional fermented sausages processing plants in Italy. Ital. J. Food Sci. 2012, 24, $214-222$.

88. Markkula, A.; Autio, T.; Lundén, J.; Korkeala, H. Raw and processed fish show identical Listeria monocytogenes genotypes with pulsed-field gel electrophoresis. J. Food Prot. 2005, 68, 1228-1231. [CrossRef] [PubMed]

89. Simões, M.; Simões, L.C.; Vieira, M.J. A review of current and emergent biofilm control strategies. LWT-Food Sci. Technol. 2010, 43, 573-583.

90. Van der Veen, S.; Abee, T. Mixed species biofilms of Listeria monocytogenes and Lactobacillus plantarum show enhanced resistance to benzalkonium chloride and paracetic acid. Int. J. Food Microbiol. 2011, 144, 421-431. [CrossRef]

91. Meloni, D.; Consolati, S.G.; Mazza, R.; Mureddu, A.; Fois, F.; Piras, F.; Mazzette, R. Presence and molecular characterization of the major serovars of Listeria monocytogenes in ten Sardinian fermented sausage processing plants. Meat Sci. 2014, 97, 443-450. [CrossRef]

92. Tompkin, R.B. Control of Listeria monocytogenes in the food-processing environment. J. Food Prot. 2002, 65, 709-725. [CrossRef]

93. Verghese, B.; Lok, M.; Wen, J.; Alessandria, V.; Chen, Y.; Kathariou, S.; Knabel, S. comK prophage junction fragments as markers for Listeria monocytogenes genotypes unique to individual meat and poultry processing plants and a model for rapid niche-specific adaptation, biofilm formation and persistence. Appl. Environ. Microbiol. 2011, 77, 3279-3292. [CrossRef]

94. Zhao, T.; Doyle, M.P.; Zhao, P. Control of Listeria monocytogenes in a biofilm by competitive-exclusion microorganisms. Appl. Environ. Microbiol. 2004, 7, 3996-4003. [CrossRef] [PubMed]

95. Samelis, J.; Metaxopoulos, J. Incidence and principal sources of Listeria spp. and Listeria monocytogenes contamination in processed meats and a meat processing plant. Food Microbiol. 1999, 16, 465-477. [CrossRef] 
96. Villani, F.; Casaburi, A.; Pennacchia, C.; Filosa, L.; Russo, F.; Ercolini, D. The microbial ecology of the Soppressata of Vallo di Diano, a traditional dry fermented sausage from Southern Italy, and in vitro and in situ selection of autochthonous starter cultures. Appl Environ. Microbiol. 2007, 73, 5453-5463. [CrossRef] [PubMed]

97. Ordóñez, J.A.; de la Hoz, L. Mediterranean products. In Handbook of Fermented Meat and Poultry; Toldrà, F., Ed.; Blackwell Publishing: Ames, IA, USA, 2007; pp. 333-347.

98. Ruggeri, A.; Carraro, V.; Succa, S.; Meloni, B.; Sanna, A.; Sanna, C.; Espa, A.; Pinna, A.; Carrucciu, G.; Grosso, M.; et al. Influence of water activity on Listeria monocytogenes growth in "Salsiccia Sarda" fermented sausage. Ital. J. Food Sci. 2018, 30, 75-88.

99. Leistner, L. Basic aspects of food preservation by hurdle technology. Int. J. Food Microbiol. 2000, 55, 181-186. [CrossRef]

100. Barbuti, S.; Parolari, G. Validation of manufacturing process to control pathogenic bacteria in typical dry fermented products. Meat Sci. 2002, 62, 323-329. [CrossRef]

101. Leistner, L. Principles and applications of hurdle technology. In New Methods of Food Preservation; Gould, G.W., Ed.; Springer: Berlin, Germany, 1995; pp. 1-21.

102. Cocolin, L.; Dolci, P.; Rantsiou, K. Biodiversity and dynamics of meat fermentations: the contribution of molecular methods for a better comprehension of a complex ecosystem. Meat Sci. 2011, 89, 296-302. [CrossRef]

103. Garriga, M.; Aymerich, T. The microbiology of fermentation and ripening. In Handbook of Fermented Meat and Poultry; John Wiley \& Sons, Ltd.: Chichester, UK, 2015; pp. 107-115.

104. Selgas, D.; Garcia de Fernando, G.; Ordonez, J.A. Lipolytic and proteolytic activity of micrococci isolated from dry fermented sausages. Fleischwirsch Int. 1994, 2, 51-54.

105. Greco, M.; Mazzette, R.; De Santis, E.P.L.; Corona, A.; Cosseddu, A.M. Evolution and identification of lactic acid bacteria isolated during the ripening of Sardinian sausages. Meat Sci. 2005, 69, 733-739. [CrossRef]

106. Mazzette, R.; De Santis, E.P.L.; Greco, M.; Virdis, S.; Cosseddu, A.M. Micrococcaceae of "Sardinian sausage": Note I. Biochemical and metabolic characteristics. In Proceedings of the 53rd National Congress of Italian Society of Veterinary Science (SISVet), Montecatini terme, Italy, 17-19 September 1999; pp. 329-330.

107. Papa, F.; Giudici, P.; Grazia, L.; Torriani, S. Lactic-acid bacteria selection for better quality salami. Ind. Aliment. 1993, 32, 258-261.

108. Torriani, S.; Di Bucchianico, R.; Patarini, F.; Zabeo, G.; Dell'aglio, F. Presenza e caratterizzazione biotecnologia di batteri lattici e Micrococcaceae negli insaccati abruzzesi. Ind. Conserve 1994, 69, 3-9.

109. Grazia, L.; Ranieri, S.; Zambonelli, C.; Chiavari, C. Action of homofermentative and heterofermentative lactobacilli on the molding of salami. Ind. Aliment. 1998, 37, 852-855.

110. Leroy, F.; de Vuyst, L. Temperature and $\mathrm{pH}$ conditions that prevail during fermentation of sausages are optimal for production of the antilisterial bacteriocin sakacin K. Appl. Environ. Microbiol. 1999, 115, 974-981.

111. Hebert, E.M.; Raya, R.R.; Taillez, P.; de Giori, G.S. Characterization of natural isolates of Lactobacillus strains to be used as starter cultures in dairy fermentation. Int. J. Food Microbiol. 2000, 59, 19-27. [CrossRef]

112. Lucke, F.K. Utilisation of microbes to process and preserve meat. Meat Sci. 2000, 56, 105-115. [CrossRef]

113. Mauriello, G.; Villani, F. Bacteriocins in plastics. In Antimicrobial Polymers; John Wiley \& Sons, Ltd.: Chichester, UK, 2012; pp. 117-158.

114. Balciunas, E.M.; Castillo Martinez, F.A.; Todorov, S.D.; de Melo Franco, B.D.G.; Converti, A.; de Souza Oliveira, R.P. Novel biotechnological applications of bacteriocins: A review. Food Control 2013, 32, 134-142. [CrossRef]

115. Vignolo, G.; Castellano, P.; Fadda, S. Bioprotective cultures. In Handbook of Fermented Meat and Poultry; John Wiley \& Sons, Ltd.: Chichester, UK, 2015; pp. 129-138.

116. Giello, M.; La Storia, A.; De Filippis, F.; Ercolini, D.; Villani, F. Impact of Lactobacillus curvatus $54 \mathrm{M} 16$ on microbiota composition and growth of Listeria monocytogenes in fermented sausages. Food Microbiol. 2018, 72, 1-15. [CrossRef]

117. Papadimitriou, K.; Pot, B.; Tsakalidou, E. How microbes adapt to a diversity of food niches. Curr Opi. Food Sci. 2015, 2, 29-35. [CrossRef] 
118. Drosinos, E.H.; Mataragas, M.; Veskovic-Moracanin, S.; Gasparik-Reichardt, J.; Hadziosmanovic, M.; Alagic, D. Quantifying non-thermal inactivation of Listeria monocytogenes in European fermented sausages using bacteriocinogenic lactic acid bacteria or their bacteriocins: A case study for risk assessment. J. Food Prot. 2006, 69, 2648-2663. [CrossRef] [PubMed]

119. Meloni, D. Presence of Listeria monocytogenes in mediterranean-style dry fermented sausages. Foods 2015, 4 , 34-50. [CrossRef]

120. Nissen, H.; Holck, A. Survival of Escherichia coli O157:H7, Listeria monocytogenes and Salmonella kentucky in Norwegian fermented, dry sausage. Food Microbiol. 1998, 15, 273-279. [CrossRef]

121. Colak, H.; Hampikyan, H.; Ulusoy, B.; Bingol, E.B. Presence of Listeria monocytogenes in Turkish style fermented sausage (sucuk). Food Control 2007, 18, 30-32. [CrossRef]

122. Mataragas, M.; Bellio, A.; Rovetto, F.; Astegiano, S.; Greci, C.; Hertel, C. Quantification of persistence of the food-borne pathogens Listeria monocytogenes and Salmonella enterica during manufacture of Italian fermented sausages. Food Control 2015, 47, 552-559. [CrossRef]

123. Cantoni, C.; Aubert, S.D.; Valenti, M.; Comi, G.; Aubert, S. Listeria spp. in cheese and dry sausages. Ind. Aliment. 1989, 28, 1068-1070.

124. Cordano, A.M.; Rocourt, J. Occurrence of Listeria monocytogenes in food in Chile. Int. J. Food Microbiol. 2001, 70, 175-178. [CrossRef]

125. Levine, P.; Rose, B.; Green, S.; Ransom, G.; Hill, W. Pathogen testing of ready-to-eat meat and poultry products collected at federally inspected establishment in the United States, 1990 to 1999. J. Food Prot. 2001, 64, 1188-1193. [CrossRef]

126. Meloni, D.; Galluzzo, P.; Mureddu, A.; Piras, F.; Griffiths, M.; Mazzette, R. Listeria monocytogenes in RTE foods marketed in Italy: Prevalence and automated EcoRI ribotyping of the isolates. Int. J. Food Microbiol. 2009, 129, 166-173. [CrossRef]

127. Doménech, E.; Jimenez-Belenguer, A.; Amoros, J.A.; Ferrus, M.A.; Escriche, I. Prevalence and antimicrobial resistance of Listeria monocytogenes and Salmonella strains isolated in ready-to-eat foods in Eastern Spain. Food Control 2015, 47, 120-125. [CrossRef]

128. Petruzzelli, A.; Blasi, G.; Masini, L.; Calza, L.; Duranti, A.; Santarelli, S.; Fisichella, S.; Pezzotti, G.; Aquilanti, L.; Osimani, A.; et al. Occurrence of Listeria monocytogenes in salami manufactured in the Marche Region (Central Italy). J. Vet. Med. Sci. 2010, 72, 499-502. [CrossRef]

129. Adams, M.; Mitchell, R. Fermentation and pathogen control: A risk assessment approach. Int. J. Food Microbiol. 2002, 79, 75-83. [CrossRef]

130. Consigliere, R.; Meloni, D.; Mazzette, R. Key hurdles in the Mediterranean-style dry fermented sausage "Salsiccia Sarda" as influenced by different ingredients related to product safety". J. Food Process. Preserv. 2018, 42, 1-8. [CrossRef]

131. Hospital, X.F.; Hierro, E.; Fernández, M. Survival of Listeria innocua in dry fermented sausages and changes in the typical microbiota and volatile profile as affected by the concentration of nitrate and nitrite. Int. J. Food Microbiol. 2012, 153, 395-401. [CrossRef] [PubMed]

132. McLauchlin, J.; Mitchell, R.T.; Smerdon, W.J.; Jewell, K. Listeria monocytogenes and listeriosis: A review of hazard characterization for use in microbiological risk assessment of foods. Int. J. Food Microbiol. 2004, 92, 15-33. [CrossRef]

133. Greenwood, M.; Roberts, H.D.; Burden, P. The occurrence of Listeria species in milk and dairy products: A national survey in England and Wales. Int. J. Food Microbiol. 1991, 12, 197-206. [CrossRef]

134. Hayes, P.S.; Graves, L.M.; Ajello, G.W.; Swaminathan, B.; Weaver, R.E.; Wenger, J.D.; Schuchat, A.; Broome, C.V. Comparison of cold-enrichment and U.S. Department of Agriculture methods for isolating Listeria spp. from naturally contaminated foods. Appl. Environ. Microbiol. 1991, 57, 2109-2113.

135. Mertens, B. Hydrostatic pressure treatment of food: equipment and processing. In New Methods of Food Preservation; Gould, G.W., Ed.; New York Blackie Academic Professional: New York, NY, USA, 1995; pp. 135-145.

136. Hogan, E.; Kelly, A.; Sun, D.W. High pressure processing of foods: An overview. Food Sci Tech. 2005, 1, 1-27.

137. Smelt, J.P.P.M. Recent advances in the microbiology of high pressure processing. Trends Food Sci. Technol. 1998, 9, 152-158. [CrossRef] 
138. De Alba, M.; Bravo, D.; Medina, M.; Park, S.F.; Mackey, B.M. Combined effect of sodium nitrite with high-pressure treatments on the inactivation of Escherichia coli BW25113 and Listeria monocytogenes NCTC 11994. Lett. Appl. Microbiol. 2013, 56, 155-160. [CrossRef]

139. Balasubramanian, S.; Balasubramaniam, V.M. Compression heating influence of pressure transmitting fluids on bacteria inactivation during high pressure processing. Food Res. Int. 2003, 36, 661-668. [CrossRef]

140. Considine, K.M.; Kelly, A.M.; Fitzgerald, G.F.; Hill, C.; Sleator, R.D. High-pressure processing- effects on microbial food safety and food quality. FEMS Microbiol. Lett. 2008, 281, 1-9. [CrossRef]

141. Bruschi, C.; Komora, N.; Castro, S.M.; Saraiva, J.; Borges Ferreira, V.; Teixeira, P. High hydrostatic pressure effects on Listeria monocytogenes and L. innocua: Evidence for variability in inactivation behaviour and in resistance to pediocin bacHA-6111-2. Food Microbiol. 2017, 64, 226-231. [CrossRef]

142. Hygreeva, D.; Pandey, M.C. Novel approaches in improving the quality and safety aspects of processed meat products through high pressure processing technology-A review. Trends Food Sci. Technol. 2016, 54, 175-185. [CrossRef]

143. Possas, A.; Valdramidis, V.; García-Gimenoa, R.M.; Pérez-Rodríguez, F. High hydrostatic pressure processing of sliced fermented sausages: A quantitative exposure assessment for Listeria monocytogenes. Innov. Food Sci. Emerg. Technol. 2019, 52, 406-419. [CrossRef]

144. Myers, K.; Montoya, D.; Cannon, J.; Dickson, J.; Sebranek, J. The effect of high hydrostatic pressure, sodium nitrite and salt concentration on the growth of Listeria monocytogenes on RTE ham and turkey. Meat Sci. 2013, 93, 263-268. [CrossRef]

145. Stratakos, A.C.; Delgado-Pando, G.; Linton, M.; Patterson, M.F.; Koidis, A. Synergism between high-pressure processing and active packaging against Listeria monocytogenes in ready-to-eat chicken breast. Innov. Food Sci. Emerg. Technol. 2015, 27, 41-47.

146. Jofré, A.; Garriga, M.; Aymerich, T. Inhibition of Listeria monocytogenes in cooked ham through active packaging with natural antimicrobials and high-pressure processing. J. Food Prot. 2007, 70, 2498-2502. [CrossRef]

147. Marcos, B.; Aymerich, T.; Monfort, J.M.; Garriga, M. High-pressure processing and antimicrobial biodegradable packaging to control Listeria monocytogenes during storage of cooked ham. Food Microbiol. 2008, 25, 177-182. [CrossRef]

148. Marcos, B.; Jofré, A.; Aymerich, T.; Monfort, J.M.; Garriga, M. Combined effect of natural antimicrobials and high pressure processing to prevent Listeria monocytogenes growth after a cold chain break during storage of cooked ham. Food Control 2008, 19, 76-81. [CrossRef]

149. Jofré, A.; Garriga, M.; Aymerich, T. Inhibition of Salmonella sp. Listeria monocytogenes and Staphylococcus aureus in cooked ham by combining antimicrobials, high hydrostatic pressure and refrigeration. Meat Sci. 2008, 78, 53-59. [CrossRef]

150. Liu, G.; Wang, Y.; Gui, M.; Zheng, H.; Dai, R.; Li, P. Combined effect of high hydrostatic pressure and enterocin LM-2 on the refrigerated shelf life of ready to-eat sliced vacuum-packed cooked ham. Food Control 2012, 24, 64-71. [CrossRef]

151. Bover-Cid, S.; Serra-Castelló, C.; Dalgaard, P.; Garriga, M.; Jofré, A. New insights on Listeria monocytogenes growth in pressurised cooked ham: A piezo-stimulation effect enhanced by organic acids during storage. Int. J. Food Microbiol. 2019, 290, 150-158. [CrossRef] [PubMed]

152. Stollewerk, K.A.; Jofré, A.; Comaposada, J.B.; Arnau, J.B.; Garriga, M. The effect of NaCl-free processing and high pressure on the fate of Listeria monocytogenes and Salmonella on sliced smoked dry-cured ham. Meat Sci. 2012, 90, 472-477. [CrossRef] [PubMed]

153. Stollewerk, K.; Jofré, A.; Comaposada, J.; Arnau, J.; Garriga, M. NaCl-free processing, acidification, smoking and high pressure: Effects on growth of Listeria monocytogenes and Salmonella enterica in QDS processed@dry-cured ham. Food Control 2013, 35, 56-64. [CrossRef]

154. Jofré, A.; Aymerich, T.; Grèbol, N.; Garriga, M. Efficiency of high hydrostatic pressure at $600 \mathrm{MPa}$ against food-borne microorganisms by challenge tests on convenience meat products. LWT -Food Sci. Technol. 2009, 42, 924-928. [CrossRef]

155. Hereu, A.; Dalgaard, P.; Garriga, M.; Aymerich, T.; Bover-Cid, S. Modeling the high pressure inactivation kinetics of Listeria monocytogenes on RTE cooked meat products. Innov. Food Sci. Emerg. Technol. 2012, 16, 305-315. [CrossRef] 
156. Marcos, B.; Aymerich, T.; Garriga, M. Evaluation of High-Pressure Processing as an Additional Hurdle to Control Listeria monocytogenes and Salmonella enterica in Low-Acid Fermented Sausages. J. Food Sci. 2005, 70, m339-m344. [CrossRef]

157. Jofré, A.; Aymerich, T.; Garriga, M. Improvement of the food safety of low acid fermented sausages by enterocins A and B and high pressure. Food Control 2009, 20, 179-184. [CrossRef]

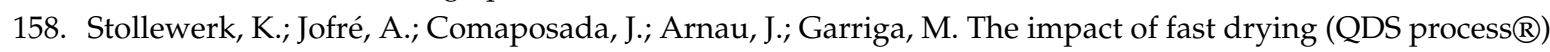
and high pressure on food safety of $\mathrm{NaCl}$-free processed dry fermented sausages. Innov. Food Sci. and Emerg. Technol. 2012, 16, 89-95. [CrossRef]

159. Marcos, B.; Aymerich, T.; Garriga, M.; Arnau, J. Active packaging containing nisin and highpressure processing as post-processing listericidal treatments for convenience fermented sausages. Food Control 2013, 30, 325-330. [CrossRef]

160. Rubio, B.; Possas, A.; Rincón, F.; García-Gímeno, R.M.; Martínez, B. Model for Listeria monocytogenes inactivation by high hydrostatic pressure processing in Spanish chorizo sausage. Food Microbiol. 2018, 69, 18-24. [CrossRef]

(C) 2019 by the author. Licensee MDPI, Basel, Switzerland. This article is an open access article distributed under the terms and conditions of the Creative Commons Attribution (CC BY) license (http://creativecommons.org/licenses/by/4.0/). 